\title{
SIMULASI PERTUMBUHAN DAN HASIL MENGGUNAKAN SIKLUS TEBANG 25, 30 DAN 35 TAHUN PADA SISTEM TEBANG PILIH TANAM INDONESIA
}

\author{
(Growth and Yield Simulation Using 25, 30, and 35 Years Cutting Cycles \\ on Indonesian Selective Cutting and Planting System) \\ Wahyudi \\ Jurusan Kehutanan, Fakultas Pertanian, Universitas Palangka Raya \\ E-mail: isanautama@yahoo.com \\ Naskah masuk : 12 Agustus 2011; Naskah diterima : 24 Mei 2012
}

\begin{abstract}
Cutting cycle of the production natural forest management oftenly changes. Simulation of cutting cycle could assist estimation of ripe trees density in the next cutting cycle. This research aimed to project growth and yield of residual trees especially the ripe trees density in the second cycle using 25, 30 and 35 years cutting cycle. Research was conducted in permanent sample plot (PSP) series of Indonesian Selective Cutting and Planting System in PT Gunung Meranti forest concession area, Central Kalimantan Province. Area of PSP series was 6 ha which measured at year 1998, 2000, 2002, 2005, and 2010. Simulation model used Stella 9.0.2 in the form of flow chart of tree diameter classes i.e. 10-19 cm, $20-29 \mathrm{~cm}, 30-39 \mathrm{~cm}, 40-49 \mathrm{~cm}, 50-59 \mathrm{~cm}$, and $60 \mathrm{~cm}$ up. These model uses equations of ingrowth, upgrowth, mortality, stand density dynamics $(\mathrm{N} / \mathrm{ha})$ and basal area dynamics $(\mathrm{B} / \mathrm{ha})$ of residual trees. Research result showed that density of ripe trees in the second cycle of 25, 30, and 35 years were 11.85 trees/ha, 15.48 trees/ha, and 17.13 trees/ha. Production target of wood have to be adapted by dynamic of residual trees growth. This simulation model could give the realistic projection of production target base on cutting cylcle, structure and composition of residual trees.
\end{abstract}

Keywords: Second cutting cycle, simulation model, residual trees, ripe trees

\begin{abstract}
ABSTRAK
Penerapan siklus tebang pada pengelolaan hutan alam produksi sering berubah-ubah. Simulasi siklus tebang dapat memproyeksikan jumlah pohon masak tebang pada siklus tebang berikutnya. Penelitian ini bertujuan untuk memprediksi pertumbuhan dan hasil tegakan tinggal, khususnya jumlah pohon masak tebang pada siklus kedua menggunakan siklus tebang 25, 30 dan 35 tahun. Penelitian dilakukan di plot penelitian (seri Petak Ukur Permanen/PUP) sistem TPTI di areal kerja PT. Gunung Meranti, Provinsi Kalimantan Tengah. Luas seri PUP adalah 6 ha dan pengambilan data dilakukan tahun 1998, 2000, 2002, 2005 dan 2010. Pemodelan dan simulasi menggunakan Stella 9.0.2 dalam bentuk diagram alir diameter pohon pada kelas diameter $10-19 \mathrm{~cm}, 20-29 \mathrm{~cm}, 30-39 \mathrm{~cm}, 40-49 \mathrm{~cm}, 50-59 \mathrm{~cm}$ dan $60 \mathrm{~cm}$ ke atas. Model ini menggunakan persamaan ingrowth, upgrowth, mortality, dinamika kerapatan tegakan $(\mathrm{N} / \mathrm{ha})$ dan dinamika luas bidang dasar (B/ha) tegakan tinggal. Hasil penelitian menunjukkan bahwa kerapatan pohon masak tebang pada siklus tebang kedua sebesar 11,85 pohon/ha, 15,48 pohon/ha dan 17,13 pohon/ha masing-masing pada penerapan siklus tebang 25, 30 dan 35 tahun. Target produksi kayu sebaiknya menyesuaikan dinamika tegakan tinggal. Model simulasi ini dapat memberi gambaran yang realistis terhadap target produksi kayu berdasarkan siklus tebang, struktur dan komposisi tegakan tinggal.
\end{abstract}

Kata kunci : Siklus tebang kedua, model simulasi, tegakan tinggal, pohon masak tebang 


\section{PENDAHULUAN}

\section{A. Latar Belakang}

Sistem tebang pilih telah digunakan untuk pengelolaan hutan alam produksi sejak tahun 1972, yang ditandai dengan pemberlakuan sistem Tebang Pilih Indonesia (TPI) berdasarkan Surat Keputusan Dirjen Kehutanan Nomor 35/Kpts/DD/I/1972 tanggal 13 Maret 1972. Sistem ini kemudian diganti dengan sistem Tebang Pilih Tanam Indonesia (TPTI) berdasarkan Surat Keputusan Menteri Kehutanan Nomor 485/Kpts/II/1989 yang dijabarkan dalam Keputusan Dirjen Pengusahaan Hutan Nomor 564/Kpts/IV-BPHH/1989 tentang Pedoman Tebang Pilih Tanam Indonesia. Revisi pertama sistem TPTI dilakukan pada tahun 1993 berdasarkan Keputusan Dirjen Pengusahaan Hutan Nomor 151/Kpts/IV-BPHH/1993 dan revisi kedua dilakukan tahun 2009 berdasarkan Peraturan Menteri Kehutanan No. P. 11/MenhutII/2009 serta Peraturan Dirjen Bina Produksi Kehutanan Nomor P.9/VI-BPHA/2009.

Ketentuan siklus tebang pada sistem tebang pilih sering berubah-ubah. Pada sistem TPI, apabila menggunakan siklus tebang 35 tahun maka harus menetapkan limit diameter pohon tebang $50 \mathrm{~cm}$, pohon inti sebanyak 25 pohon/ha dengan batas diameter $\geq 35 \mathrm{~cm}$. Apabila menggunakan siklus tebang 45 tahun maka harus menetapkan limit diameter pohon tebang sebesar $40 \mathrm{~cm}$, dan apabila menggunakan siklus tebang 55 tahun maka harus menetapkan limit diameter pohon tebang sebesar $30 \mathrm{~cm}$ dengan 40 pohon inti/ha berdiameter $\geq 25 \mathrm{~cm}$. Sistem TPTI tahun 1989 menerapkan siklus tebang 35 tahun dengan pohon inti sebanyak 25 pohon/ha dan limit diameter pohon tebang sebesar $50 \mathrm{~cm}$ untuk hutan produksi dan $60 \mathrm{~cm}$ untuk hutan produksi terbatas. Berdasarkan Permenhut No. P.11/Menhut-II/2009, ketentuan siklus tebang sistem TPTI mengalami perubahan, yaitu 30 tahun dengan limit diameter $40 \mathrm{~cm}$ untuk hutan produksi dan hutan konversi serta $50 \mathrm{~cm}$ untuk hutan produksi terbatas. Kebijakan tersebut juga menetapkan siklus tebang 25 tahun pada sistem Tebang Pilih Tanam Jalur (TPTJ).

Semua perubahan yang dilakukan tersebut bertujuan untuk menyempurnakan sistem silvikultur tebang pilih agar lebih efektif dalam mewujudkan kelestarian hutan (sustained forest) termasuk kelestarian produksi (sustained yield). Namun tujuan tersebut belum pernah terbukti karena perubahan telah dilakukan meskipun sistem dan ketentuannya belum mencapai satu siklus tebang. Oleh sebab itu diperlukan metode untuk menguji efektivitas pencapaian tujuan tersebut tanpa harus menunggu waktu siklus tebangnya tiba. Pemodelan dan simulasi beberapa siklus tebang yang pernah diterapkan dalam sistem tebang pilih di Indonesia merupakan langkah yang tepat dalam rangka mendapatkan gambaran kelestarian hutan yang ditunjukkan dengan pulihnya kondisi tegakan seperti semula.

Kelestarian produksi hasil hutan kayu pada sistem TPTI ditentukan oleh ketersediaan pohon yang masak tebang jenis komersial yang memenuhi kriteria limit diameter pohon tebang, yaitu $40 \mathrm{~cm}$ ke atas untuk hutan produksi dan 50 $\mathrm{cm}$ ke atas pada hutan produksi terbatas. Pada hutan produksi terbatas ketersediaan pohon masak tebang pada siklus tebang berikutnya ditentukan oleh ketersediaan pohon inti berdiameter 20-49 $\mathrm{cm}$ periode sebelumnya, sedangkan ketersediaan pohon inti ditentukan oleh ketersediaan permudaan tingkat tiang dan seterusnya. Kerapatan pohon masak tebang berdiameter $50 \mathrm{~cm}$ ke atas di hutan primer sebesar 13,41 pohon/ha (PT. GM, 2000).

Tegakan tinggal pada hutan alam campuran bekas tebangan tersusun dari permudaan tingkat semai, pancang, tiang dan pohon yang mengalami dinamika menuju ke arah klimak. Dinamika ini merupakan fungsi dari struktur dan komposisi tegakan tinggal (Indrawan, 2003), intensitas penebangan (Elias et al., 1997) serta faktor klimatis (curah hujan, kelembaban, intensitas cahaya, suhu) dan faktor edafis (sifat fisik, kimia dan biologi tanah).

Menurut Buongiorno dan Michie (1980) serta Vanclay (2001) pemodelan hutan campuran dapat memanfaatkan dinamika luas bidang dasar (B/ha) dan kerapatan tegakan (N/ha) yang diperoleh dari hasil pengukuran minimal 4 kali. Untuk mendapatkan data luas bidang dasar maka pengukuran tegakan tinggal dilakukan mulai tingkat tiang (10 $\mathrm{cm}$ ke atas). Tegakan tinggal pada tingkat tiang ke atas inilah yang paling menentukan persaingan tempat tumbuh dalam ekosistem hutan campuran karena mempunyai dominasi, kerapatan dan frekwensi yang tinggi. Sehubungan dengan hal tersebut, maka pemodelan dinamika hutan alam produksi bekas tebangan dapat menggunakan tegakan tinggal tingkat tiang ke atas. 


\section{B. Tujuan dan Manfaat}

Tujuan penelitian adalah:

1. Membangun model dinamika pertumbuhan tegakan tinggal tingkat tiang dan pohon sistem TPTI

2. Memprediksi jumlah pohon masak tebang pada sistem TPTI menggunakan simulasi model siklus tebang 25,30 dan 35 tahun.

Hasil simulasi model ini dapat bermanfaat untuk menentukan siklus tebang yang paling baik berdasarkan komposisi floristik vegetasi, dinamika luas bidang dasar (B) dan kerapatan tegakan (N) dalam rangka mewujudkan pengelolaan hutan yang lestari.

\section{METODE PENELITIAN}

\section{A. Tempat dan Waktu}

Penelitian dilakukan di seri Petak Ukur Permanen (PUP) pada petak AU34 blok tebangan tahun 1997, kawasan hutan produksi terbatas IUPHHK-HA PT. Gunung Meranti, di Kabupaten Kapuas, Provinsi Kalimantan Tengah (Gambar 1). Pengambilan data dilakukan setiap bulan September tahun 1998 (Et+1), 2000

\section{B. Prosedur Penelitian}

1. Seri PUP terdiri dari 6 PUP masing-masing dengan luas 1 ha $(100 \mathrm{~m} \times 100 \mathrm{~m})$ yang terbagi dalam 100 plot penelitian berukuran $10 \mathrm{~m} \times 10 \mathrm{~m}$. Pengukuran seri PUP dilakukan secara sensus terhadap semua jenis pohon berdiameter $10 \mathrm{~cm}$ ke atas. Layout PUP disajikan dalam Gambar 2.

2. Rekapitulasi data PUP dilakukan berdasarkan hasil pengukuran tahun 1998, 2000, 2002, 2005 dan 2010.

3. Menghitung dinamika kerapatan $(\mathrm{N} / \mathrm{ha})$ dan luas bidang dasar $(\mathrm{B} / \mathrm{ha})$ tegakan tinggal tahun 1998, 2000, 2002, 2005 dan 2010 pada diameter 10-19 cm, 20-29 cm, 30-39 cm, $40-49 \mathrm{~cm}, 50-59 \mathrm{~cm}$ dan $60 \mathrm{~cm}$ ke atas.

4. Membuat persamaan ingrowth, upgrowth dan mortality tegakan tinggal pada kelompok meranti, kelompok dipterocarp non-meranti dan kelompok komersial lain yang terdiri dari kelompok rimba campuran, kayu indah dan jenis lain.

5. Menyusun model diagram alir dinamika tegakan tinggal dengan asumsi tidak ada penebangan sebelum mencapai daur yang ditetapkan.

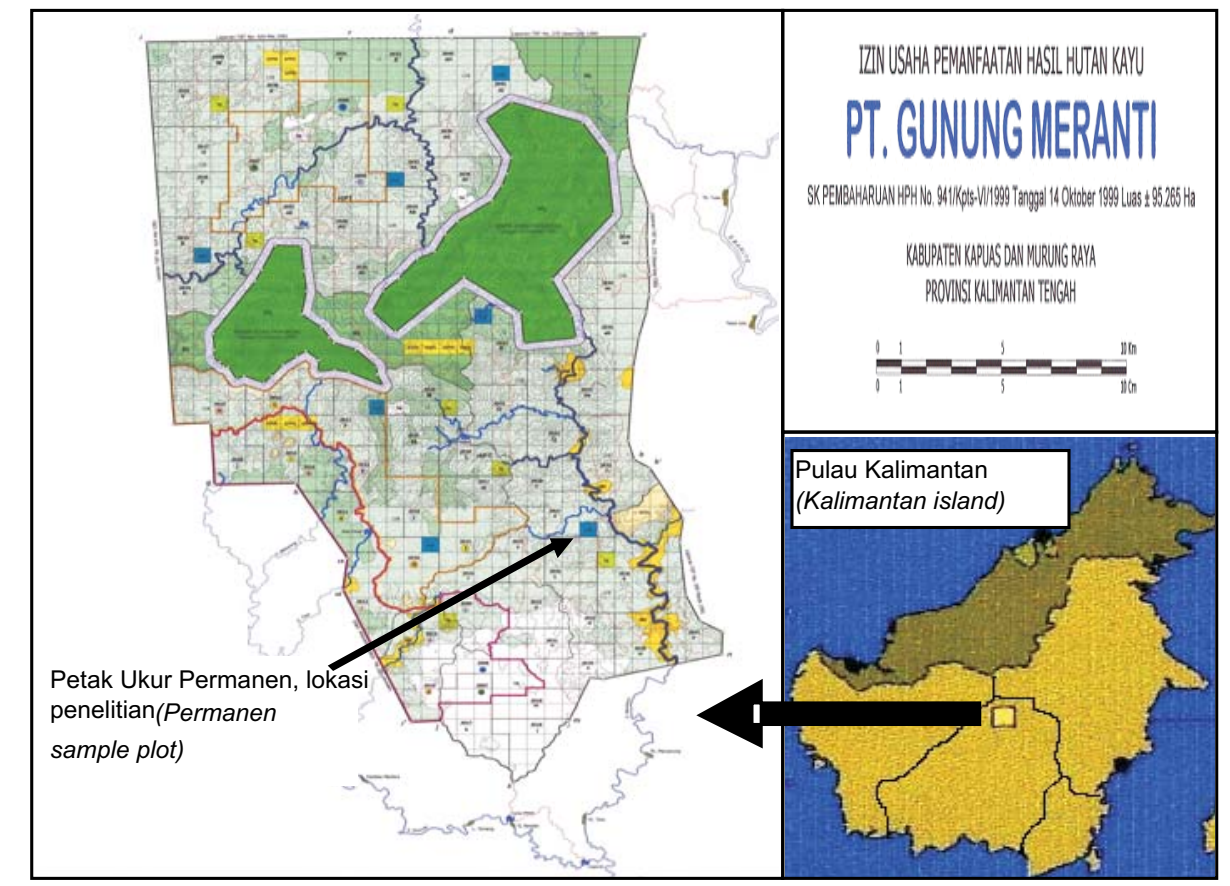

Gambar(Figure) 1. Peta IUPHHK-HA PT Gunung Meranti di Provinsi Kalimantan Tengah (IUPHHKHA PT. Gunung Meranti map in Central Kalimantan Province) 


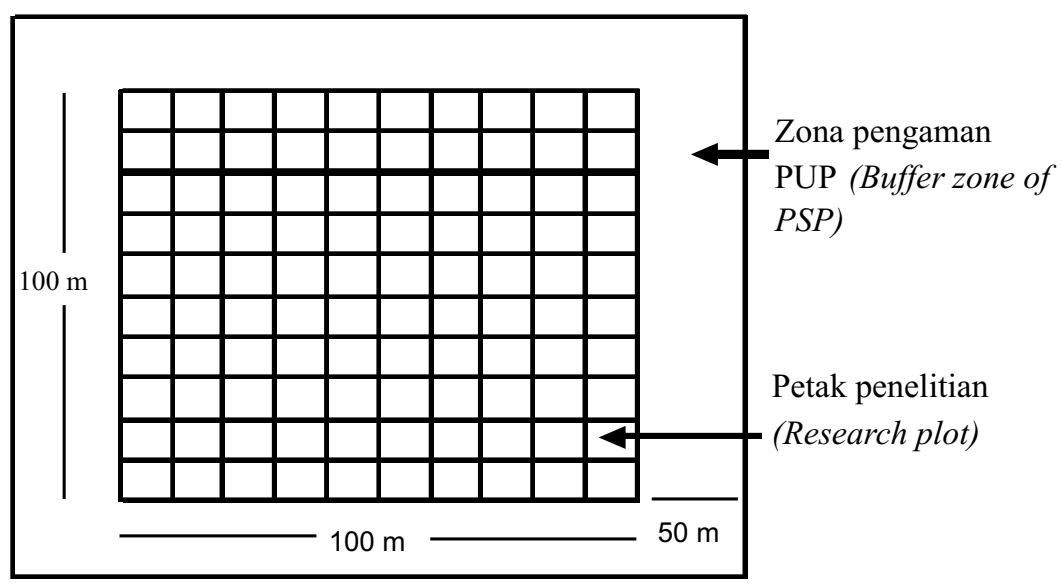

Gambar (Figure) 2. Layout Petak Ukur Permanen (Layout of permanen sample plot)

6. Melakukan evaluasi model menggunakan chi square

7. Membangun model pertumbuhan dan hasil menggunakan simulasi model siklus tebang 25, 30 dan 35 tahun.

8. Memproyeksikan jumlah pohon masak tebang dengan skenario menggunakan siklus tebang 25, 30 dan 35 tahun. Pohon yang ditebang.

\section{Analisis Data}

1. Ingrowth adalah banyaknya pohon yang masuk ke dalam kelas diameter terkecil selama satu tahun pada luasan satu hektar. Dalam penelitian ini ingrowth adalah jumlah pohon per tahun yang memasuki tingkat tiang atau telah mencapai diameter $10 \mathrm{~cm}$ ke atas. Persamaan ingrowth berdasarkan fungsi kerapatan pohon dan luas bidang dasar total (Buongiorno dan Michie, 1980; Vanclay, 2001) sebagai berikut:

$\mathrm{I}_{\mathrm{i}}=\mathrm{a}+\mathrm{bN}+\mathrm{eB}$

dimana: $\mathrm{I}_{\mathrm{i}}=$ ingrowth pada kelompok pohon ke-i (phn/ha/th)

$\mathrm{N}=\operatorname{kerapatan}(\mathrm{phn} / \mathrm{ha})$

$\mathrm{B}=$ luas bidang dasar $\left(\mathrm{m}^{2} / \mathrm{ha}\right)$ $\mathrm{a}, \mathrm{b}, \mathrm{e}=$ koefisien regresi

2. Upgrowth adalah banyaknya pohon yang masuk ke dalam kelas diameter tertentu yang berasal dari kelas diameter di bawahnya dalam waktu satu tahun per ha. Upgrowth ditentukan berdasarkan fungsi diameter ratarata dan luas bidang dasar (Favrichon dan Kim, 1998) sebagai berikut:

$\mathrm{Up}_{\mathrm{ij}}=C_{I}+\mathrm{C}_{2} \mathrm{D}_{\mathrm{j}} \mathrm{C}_{3} \mathrm{D}_{\mathrm{j}}^{2}+\mathrm{C}_{4} \mathrm{D}_{\mathrm{j}}^{3}-\mathrm{C}_{\mathrm{i} 4} \mathrm{~B}_{\mathrm{t}}$

dimana:
$\mathrm{Up}_{\mathrm{ij}}=$ upgrowth kelompok pohon ke-i pada kelas diameter ke-j (phn/ha/th)

$\mathrm{C}=$ koefisien regresi

$\mathrm{D}_{\mathrm{j}}=$ rataan diameter pada kelas diameter ke-j $(\mathrm{cm})$

$\mathrm{Bt}=$ luas bidang dasar pada saat tahun ke- $\mathrm{t}$

3. Mortality adalah banyaknya pohon yang mati alami dan mati akibat efek penebangan dalam waktu satu tahun per ha. Mortality akibat efek penebangan tidak dipengaruhi oleh kerapatan tegakan. Penelitian ini menggunakan persamaan mortality berdasarkan fungsi diameter rata-rata dalam kelas diameter masing-masing (Favrichon, 1998) sebagai berikut:

$\mathrm{M}_{\mathrm{ij}}=C_{l}+\mathrm{C}_{2} \mathrm{D}_{\mathrm{j}}-\mathrm{C}_{3} \mathrm{D}_{\mathrm{j}}^{2}+\mathrm{C}_{4} \mathrm{D}_{\mathrm{j}}^{3}$

dimana:

$\mathrm{M}_{\mathrm{ij}}=$ mortality kelompok pohon ke-i pada kelas diameter ke-j (phn/ha/th)

$\mathrm{C}=$ koefisien regresi

$\mathrm{D}_{\mathrm{j}}=$ rataan diameter pada kelas diameter ke-j (cm)

4. Pemodelan menggunakan dimensi diameter pertengahan (D) tiap kelas diameter, kerapatan (N/ha) dan luas bidang dasar tegakan (LBD/ha) yang dibuat dalam bentuk diagram alir mulai dari kelas diameter 10-19 $\mathrm{cm}, 20-29 \mathrm{~cm}, 30-39 \mathrm{~cm}, 40-49 \mathrm{~cm}, 50-59 \mathrm{~cm}$ dan $60 \mathrm{~cm}$ ke atas. Pemodelan diagram alir menggunakan perangkat lunak Stella 9.0.2 seperti terlihat pada Gambar 2.

5. Evaluasi model dilakukan dengan membandingkan hasil proyeksi struktur dan komposisi tegakan pada model (expected) dengan data dinamika struktur dan komposisi tegakan hasil pengukuran langsung di 
lapangan (observed) menggunakan uji chi kuadrat sebagai berikut:

$$
\begin{aligned}
\chi^{2}=\sum_{\mathrm{i}=1}^{\mathrm{n}} \frac{\left(\mathrm{O}_{\mathrm{i}}-\mathrm{E}_{\mathrm{i}}\right)^{2}}{\mathrm{E}_{\mathrm{i}}} & \\
\text { dimana: } & \mathrm{O}_{\mathrm{i}}=\text { data aktual (observed) } \mathrm{ke}-\mathrm{i} \\
\mathrm{E}_{\mathrm{i}} & =\text { data dugaan/hasil pemodelan } \\
\mathrm{n} & =\text { (expected) } \mathrm{ke}-\mathrm{i}
\end{aligned}
$$

Kriteria uji: $\chi^{2}$ hit $<\chi^{2}$ tabel: Terima $\mathrm{H}_{0}$ (model handal)

$\chi^{2}$ hit $\geq \chi^{2}$ tabel: Terima $\mathrm{H}_{1}$ (model tidak handal)

\section{HASIL DAN PEMBAHASAN}

\section{A. Ingrowth}

Ingrowth digambarkan melalui persamaan regresi yang dibangun menggunakan kerangka pikir berdasarkan jumlah pohon yang masuk dalam kelas diameter di atasnya dalam waktu satu tahun. Dalam merancang pemodelan dinamika hutan ini, ingrowth merupakan fungsi dari luas bidang dasar tegakan (B) dan kerapatan (N) (Buongiorno and Michie, 1980; Coates, 2002 dalam FylIas et al., 2010; Vancly, 2001). Pada penelitian ini ingrowth merupakan perpindahan dari tingkat pancang ke dalam tingkat tiang. Persamaan ingrowth yang dihasilkan sebagai berikut:

1. Kelompok meranti $\rightarrow \mathrm{i}=12,3906-0,3198 \mathrm{~N}+$ $0,3947 \mathrm{~B}\left(\mathrm{R}^{2}=0,547\right)$

2. Kelompok dipterocarp non meranti $\rightarrow \mathrm{i}=$ $2,7261+0,0289 \mathrm{~N}-0,1396 \mathrm{~B}\left(\mathrm{R}^{2}=0,22\right)$

3. Kelompok komersia llain $\rightarrow \mathrm{i}=76,25 \mathrm{~S} 1$ $0,4653 \mathrm{~N}-1,6505 \mathrm{~B}\left(\mathrm{R}^{2}=0,769\right)$

dimana: ig=ingrowth, $\mathrm{N}=$ kerapatan (phn/ha), $\mathrm{B}=$ luas bidang dasar $\left(\mathrm{m}^{2} / \mathrm{ha}\right)$.

Berdasarkan persamaan ingrowth di atas, dapat diketahui bahwa fungsi ingrowth pada kelompok meranti berbanding terbalik dengan kerapatan tegakan $(\mathrm{N})$, namun sejalan dengan luas bidang dasarnya (B), yang mengindikasikan bahwa semakin banyak jumlah pohon persatuan luas (ha) maka semakin kecil peluang terjadi ingrowth namun tidak terpengaruh dengan kerapatan yang ditunjukkan oleh luas bidang dasarnya. Pada fase ini kelompok jenis meranti sangat memerlukan ruang tumbuh yang optimal dan persaingan untuk bertahan hidup dalam komunitasnya menjadi sangat tinggi. Kondisi tersebut berlaku sebaliknya untuk kelompok dipterocarp non-meranti, yang berbanding lurus dengan jumlah pohon persatuan luas lahan (ha) namun berbanding terbalik dengan luas bidang dasar yang mampu mempresentasikan kerapatan tegakan, artinya makin tinggi kerapatan tegakan makin besar nilai ingrowth-nya. Rendahnya konsistensi indikator $\mathrm{N}$ dan $\mathrm{B}$ dalam menjalankan proses ingrowth disebabkan oleh tidak terkendalinya pengaruh berbagai faktor lingkungan yang ada, baik bersifat hayati (asosiasi berbagai jenis pohon berkayu dan non kayu serta kehidupan lain dalam hutan) maupun non hayati (faktor edafis/tapak dan klimatis) serta interaksi diantara faktor-faktor tersebut (Suhendang, 1998).

Pada kelompok komersial lain terjadi fenomena yang lebih jelas bahwa fungsi ingrowth berbanding terbalik dengan kerapatan tegakan yang dicerminkan dalam bentuk jumlah pohon per ha $(\mathrm{N} / \mathrm{ha})$ dan luas bidang dasar per ha $(\mathrm{B} / \mathrm{ha})$ dengan koefisien determinasi $76,86 \%$.

Upaya menuangkan dinamika vegetasi hutan tropis yang komplek ke dalam sebuah model masih memerlukan penelitian yang lebih mendalam dengan menggabungkan semua fungsi yang terkait. Hingga saat ini pemodelan dinamika hutan masih menggunakan beberapa komponen dasar seperti riap, kerapatan, luas bidang dasar, disturbance dan lain-lain. Hal inilah yang menyebabkan nilai koefisien determinasi pada setiap persamaan ingrowth (dan juga upgrowth dan mortality) selalu berada pada kisaran rendah sampai sedang. Sebagai perbandingan, nilai koefisien determinasi persamaan ingrowth yang ditemukan oleh Buongiomo et al. (1995) di hutan tidak seumur sebesar $37 \%-47 \%$, Volin and Buongiorno (1996) sebesar $44-53 \%$ dan Favrichon and Kim (1998) sebesar 4\% - 10\%.

\section{B. Upgrowth}

Upgrowth adalah peluang pohon yang hidup dalam kelas diameter tertentu yang pindah ke dalam kelas diameter di atasnya dalam waktu satu tahun. Upgrowth merupakan fungsi dari nilai tengah diameter (D) dan luas bidang dasar (B) (Buongiomo et al., 1995; Favrichon, 1998; Favrichon dan Kim, 1998; Fyllas et al., 2010).

Persamaan upgrowth dalam penelitian ini dibagi dalam tiga kelompok jenis, yaitu meranti, dipterocarp non-meranti serta komersial lain, sebagai berikut:

Kelompok meranti:

up $=0,1729+0,07650-0,0029 \mathrm{D}^{2}+\mathrm{O}, 0000273$

$$
\mathrm{D}^{3}-0,002 \mathrm{~B} \quad\left(\mathrm{R}^{2}=0,5356\right)
$$


Kelompok dipterocarp non meranti:

up $=0,5764+0,00480-0,00066$

$\mathrm{D}^{2}+0,00000736 \mathrm{D}^{3}-0,00023 \mathrm{~B}$

Kelompok komersial lain:

$$
\left(\mathrm{R}^{2}=0,3680\right)
$$

up $=7,1901-0,43230+0,0088 D^{2}-0,000059 D^{3}-$

$$
0,00075 \mathrm{~B} \quad\left(\mathrm{R}^{2}=0,9231\right)
$$

dimana: ug=upgrowth, $\mathrm{N}=$ kerapatan

( $\mathrm{phn} / \mathrm{ha}), \mathrm{B}=$ luas bidang dasar $\left(\mathrm{m}^{2} / \mathrm{ha}\right)$

Berdasarkan persamaan di atas, dapat diketahui bahwa upgrowth pada semua kelompok jenis berbanding terbalik dengan fungsi luas bidang dasar yang mengindikasikan bahwa semakin rapat kondisi tegakan maka semakin kecil peluang terjadi upgrowth pada semua jenis pohon di berbagai tingkatan. Pada penelitian ini upgrowth berupa perpindahan dari kelas diameter 20-29 $\mathrm{cm}$ ke 30-39 cm ke 40-49 $\mathrm{cm}$ ke 50-59 $\mathrm{cm}$ ke $60 \mathrm{~cm}$ up dan tidak mungkin terjadi lompatan berganda pada kelas diameter di atasnya karena belum pernah ada riap diameter pohon dalam hutan alam campuran di atas 10 $\mathrm{cm} /$ tahun. Hal ini sekaligus mengindikasikan bahwa semua pohon dalam tegakan hutan sangat memerlukan ruang tumbuh yang optimal untuk pertumbuhannya.

Koefisien determinasi $\left(\mathrm{R}^{2}\right)$ pada kelompok komersial lain dalam penelitian ini sangat besar, yaitu $92,31 \%$ sehingga persamaan upgrowth yang terbentuk dapat menerangkan dinamika pertumbuhannya secara lebih baik. Namun demikian nilai $\mathrm{R}^{2}$ pada kelompok meranti dan dipterocarp non-meranti masih relatif rendah, yaitu $53,56 \%$ dan $36,8 \%$. Perbedaan nilai $\mathrm{R}^{2}$ ini dapat menunjukkan bahwa kelompok jenis-jenis dari dipterocarp mempunyai kemampuan adaptasi yang cukup tinggi terhadap persaingan yang terdapat di hutan alam campuran, sebaliknya kelompok komersial lain sangat terpengaruh oleh kerapatan tegakan hutan, yaitu semakin tinggi kerapatan tegakan makin rendah ingrowth-nya. Beberapa penelitian upgrowth juga memberikan nilai koefisien determinasi yang relatif kecil, seperti pada penelitian Buongiomo et al. (1995) sebesar 1,3\% - 40\%; Volin dan Buongiorno (1996) sebesar 6\% - 14\%; Favrichon (1998) sebesar 5\% - 22\% dan Favrichon and Kim (1998) sebesar 57\% - 71\%. Menurut Suhendang (1998), rendahnya nilai determinasi di hutan alam disebabkan tidak terkendalinya pengaruh berbagai faktor lingkungan yang terdapat di dalam hutan alam campuran, baik faktor lingkungan hayati, non hayati serta interaksi diantara faktor-faktor tersebut.

\section{Mortality}

Mortality adalah banyaknya pohon yang mati dalam tegakan hutan dalam satuan waktu tertentu. Dalam penelitian mortality berarti jumlah pohon yang mati dalam kelompok dan diameter tertentu selama satu tahun. Kematian pohon dalam hutan yang dikelola dapat disebabkan faktor alam dan faktor disturbance, seperti penebangan, sehingga sulit mengaitkan kematian pohon dalam hutan ini hanya sekedar dari faktor alam saja. Berdasarkan hasil penelitian Elias et al. (1997) dan Sist and Bertault (1998) bahwa tingkat kerusakan tegakan tinggal, yang dapat bermuara pada kematian, sangat berkaitan dengan intensitas penebangan yang dilakukan. Kematian akibat pencurian kayu dan kebakaran hutan (catastropic) tidak diperhitungan dalam persamaan mortality. Persamaan mortality dalam penelitian ini sebagai berikut:

Kelompok meranti:

$\mathrm{m}=1,2667-0,0891 \mathrm{D}+0,0022 \mathrm{D}^{2}-$

$$
0,000018 \mathrm{D}^{3} \quad \mathrm{R}^{2}=0,4577
$$

Kelompok dipterocarp non meranti:

$\mathrm{m}=2,0775-0,1111 \mathrm{D}+0,00186 \mathrm{D}^{2}-$

$$
0,0000091 \mathrm{D}^{3} \quad \mathrm{R}^{2}=0,4745
$$

Kelompok komersial lain

$\mathrm{m}=5,1179-0,2896 \mathrm{D}+0,0057 \mathrm{D}^{2}-$

$$
0,000038 \mathrm{D}^{3} \quad \mathrm{R}^{2}=0,4779
$$

dimana: $\mathrm{m}=$ mortality, $\mathrm{D}=\operatorname{diameter}(\mathrm{cm})$.

Nilai koefisien determinasi dalam persamaan mortality ini berkisar antara $45,77 \%$ sampai $47,79 \%$ sehingga hanya besaran itulah yang mampu memberi informasi tingkat kematian pohon dalam hutan berdasarkan kelas diameternya. Nilai koefisien determinasi yang rendah dalam persamaan ini juga disebabkan oleh penggunaan kelompok pohon, karena membangun persamaan menggunakan individu pohon dalam hutan alam campuran sangat sulit dilakukan disebabkan jumlahnya yang sangat banyak serta kesulitan mendapatkan sampel pohon dalam setiap kelas diameternya. Faktorfaktor lain yang masih belum terakumulasi dalam persamaan ini, seperti hama penyakit, gulma, faktor edafis dan iklim mikro. Terdapat kecenderungan bahwa semakin besar diameter pohon maka semakin tinggi peluang untuk mati. Fenomena ini dapat membatasi keberadaan pohon sampai mencapai diameter yang tidak 
terbatas. Nilai koefisien determinasi pada persamaan mortality yang didapatkan beberapa peneliti lain sebesar 4\% - 79\% (Favrichon, 1998). Dengan metode yang agak berbeda, beberapa peneliti mendapatkan nilai koefisien determinasi sebesar 7\% (Buongiorno et al., 1995) dan 2\% 3\% (Volin dan Buongiorno, 1996).

Dari persamaan ingrowth, upgrowth, mortality dan kerapatan tegakan ( $\mathrm{N}$ dan $\mathrm{B})$ dapat dibentuk diagram alir dinamika pertumbuhan tegakan tinggal seperti terlihat pada Gambar 3.
Dalam diagram alir tersebut, komponen ingrowth yang masuk pada tingkat tiang hanya terjadi sekali karena penelitian ini hanya memfokuskan pada dinamika kerapatan pohon masak tebang (diameter $50 \mathrm{~cm}$ ke atas) yang diprediksi hanya berasal dari kelompok pohon berdiameter 40-49 $\mathrm{cm}$ dan 30-39 $\mathrm{cm}$. Kematian pohon akibat penebangan dihitung ketika pohon telah menunjukkan gejala kematian nyata yang dapat terjadi pada tahun pertama sampai beberapa tahun kemudian (Stuckle et al., 2001).

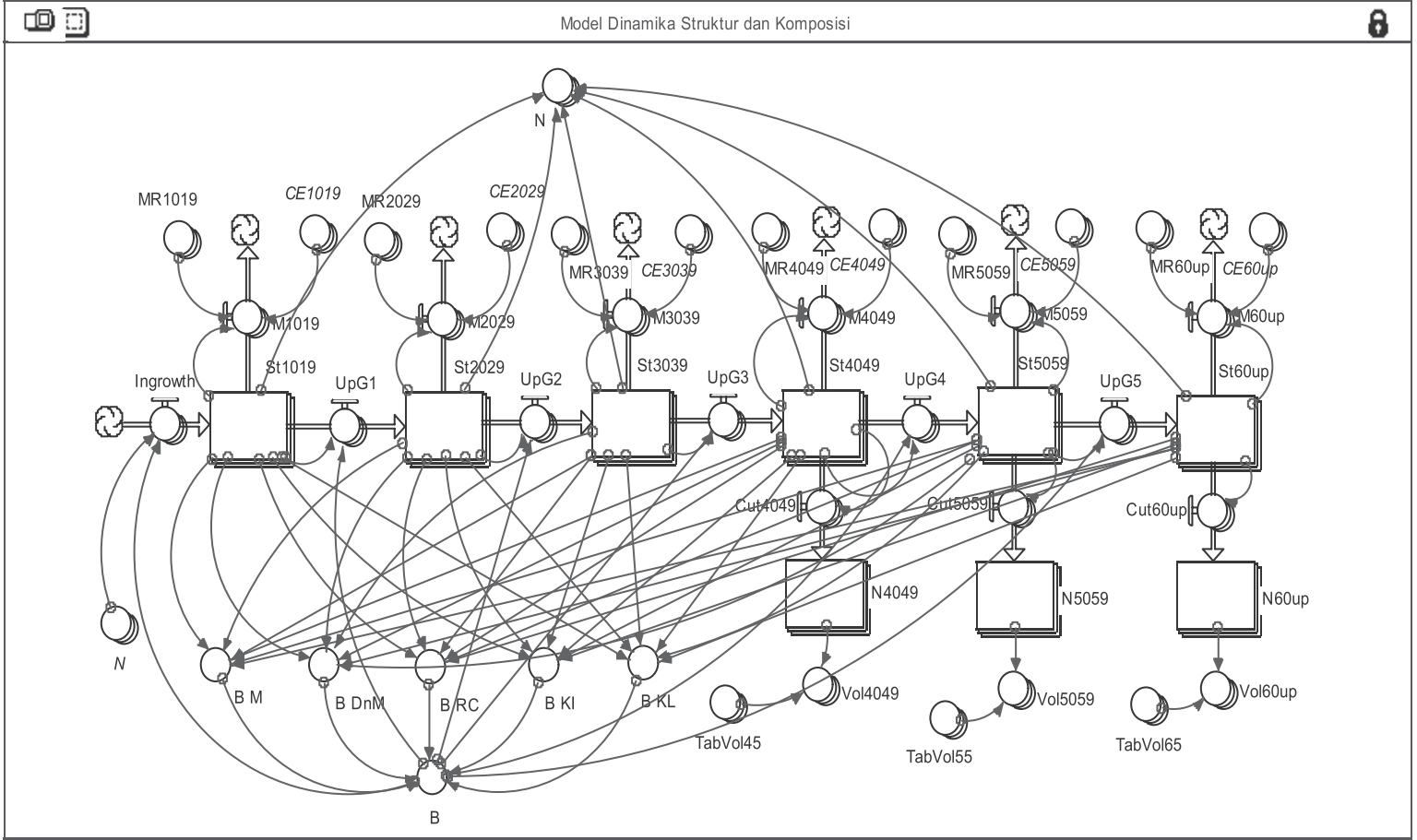

Keterangan:

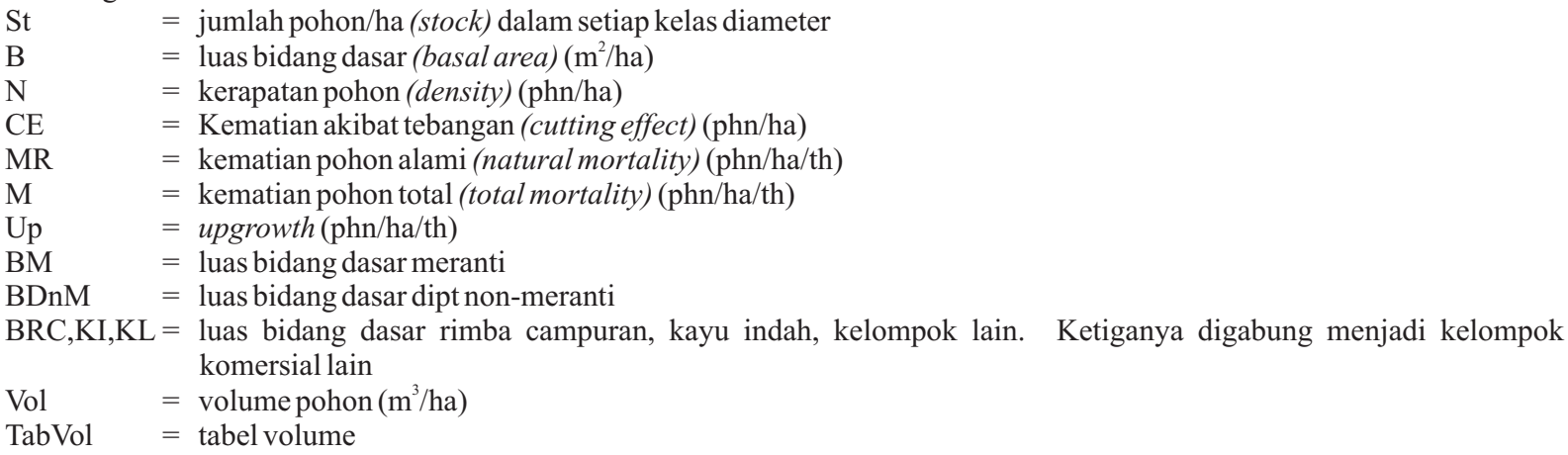

Gambar (Figure) 3. Diagram alir dinamika pertumbuhan tegakan tinggal pada hutan tidak seumur (Flow chart of residual trees dynamic at the unevenaged forest) 


\section{Simulasi Siklus Tebang}

\section{Kerapatan pohon masak tebang meng- gunakan siklus 25 tahun}

Berdasarkan hasil simulasi model diperoleh gambaran bahwa setelah 25 tahun, jumlah pohon masak tebang, berdiameter $50 \mathrm{~cm}$ ke atas, sebanyak $11,85 \mathrm{phn} / \mathrm{ha}$ yang terdiri dari kelompok meranti sebanyak 3,04 phn/ha, kelompok diptero non meranti sebanyak $0,8 \mathrm{phn} / \mathrm{ha}$ dan kelompok komersial lain sebanyak 8,01 phn/ha (Tabel 1). Simulasi model pertumbuhan tegakan tinggal menggunakan siklus tebang 25 tahun dapat dilihat pada Gambar 4.

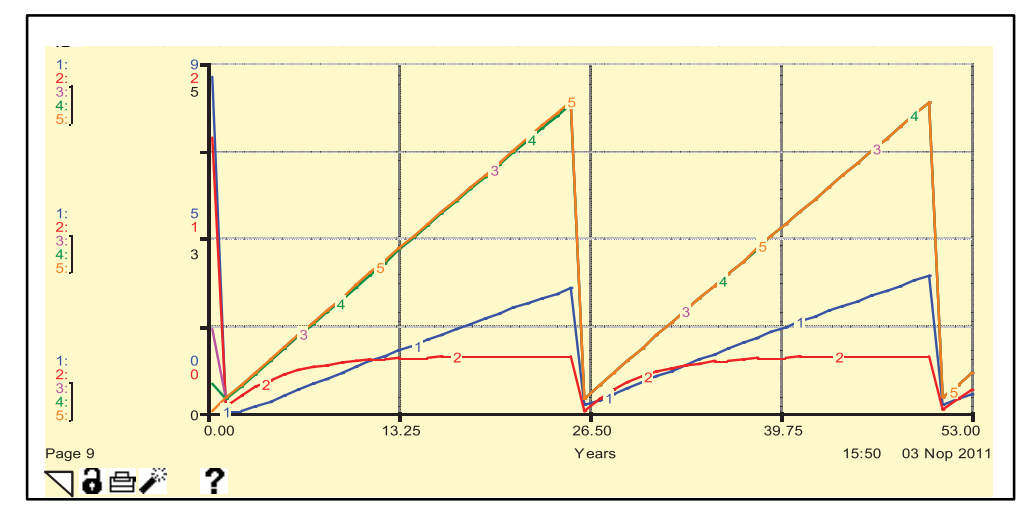

Keterangan: 1 = kelompok meranti, $2=$ kelompok diptero non meranti,

3,4,5 = kelompok komersial lain (kayu indah, rimba campuran, kelompok lain)

Gambar(Figure) 4. Simulasi model pertumbuhan tegakan tinggal pada siklus tebang 25 tahun (Growth model simulation of residual trees for 25 year cutting cycles)

\section{Kerapatan pohon masak tebang meng- gunakan siklus 30 tahun}

Berdasarkan hasil simulasi model diperoleh gambaran bahwa setelah 30 tahun, jumlah pohon masak tebang, berdiameter $50 \mathrm{~cm}$ ke atas, sebesar 15,48 phn/ha yang terdiri dari kelompok meranti sebesar 3,94 phn/ha, kelompok diptero non meranti sebesar $0,88 \mathrm{phn} / \mathrm{ha}$ dan kelompok komersial lain 10,66 phn/ha (Tabel 1). Model simulasi pertumbuhan tegakan tinggal menggunakan siklus tebang 25 tahun dapat dilihat pada Gambar 5.

\section{Kerapatan pobon masak tebang meng- gunakan siklus 35 tahun}

Berdasarkan hasil simulasi model diperoleh gambaran bahwa setelah 30 tahun, jumlah pohon masak tebang, berdiameter $50 \mathrm{~cm}$ ke atas, sebesar 17,13 phn/ha yang terdiri dari kelompok meranti sebesar 3,51 phn/ha, kelompok diptero non meranti sebesar $0,32 \mathrm{phn} / \mathrm{ha}$ dan kelompok komersiallain 13,3 phn/ha (Tabel 1). Model simulasi pertumbuhan tegakan tinggal menggunakan siklus tebang 25 tahun dapat dilihat pada Gambar 6.

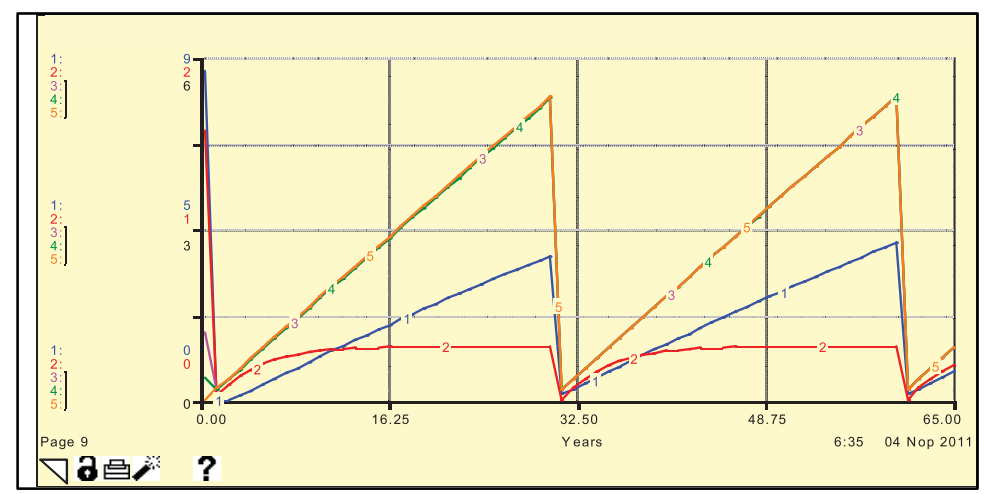

Keterangan: 1 = kelompok meranti, $2=$ kelompok diptero non meranti,

$3,4,5=$ kelompok komersial lain (kayu indah, rimba campuran, kelompok lain)

Gambar(Figure) 5. Simulasi model pertumbuhan tegakan tinggal pada siklus tebang 30 tahun (Growth model simulation of residual trees for 30 year cutting cycles) 


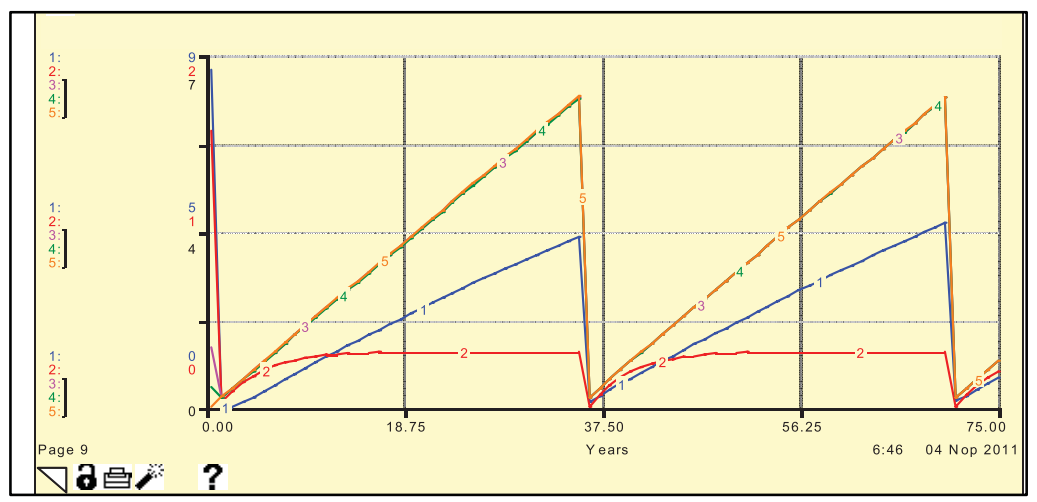

Keterangan: 1 =kelompok meranti, 2 =kelompok diptero non meranti,

$3,4,5=$ kelompok komersial lain (kayu indah, rimba campuran, kelompok lain)

Gambar(Fig) 6. Simulasi model pertumbuhan tegakan tinggal pada siklus tebang 35 tahun (Growth model simulation of residual trees for 35 year cutting cycles)

Hasil simulasi model menggunakan siklus tebang 25, 30 dan 35 tahun menunjukkan bahwa makin lama waktu yang digunakan untuk menunggu maka semakin tinggi kerapatan pohon masak tebang (Tabel 1). Kerapatan pohon masak tebang di samping dipengaruhi oleh waktu, juga tergantung pada komposisi floristik vegetasi, dinamika kerapatan dan luas bidang dasar yang merupakan cerminan dari riap tegakan tinggal serta intensitas dan target tebangan perusahaan.

Pohon masak tebang pada siklus tebang kedua didominasi oleh kelompok pohon komersial lain (kempas coklat, nyatoh, scapium, marijang, ulin, medang, keranji, geronggang, kayu bawang dan lain-lain). Komposisi seperti ini terjadi karena pada daur pertama mayoritas pohon yang ditebang berasal dari kelompok meranti dan diperocarp non-meranti, sedangkan kelompok komersial lain masih tetap mengisi tegakan tinggal. Kelompok meranti kembali muncul pada daftar pohon masak tebang karena ketersediaan pohon inti kelompok meranti pada tegakan tinggal sebelumnya. Dengan demikian target penebangan pada siklus tebang kedua sebaiknya merupakan campuran antara kelompok meranti, dipterocarp non meranti dan kelompok komersial lain sesuai kebutuhan dan tingkat kerapatan masing-masing jenis.

Tabel (Table) 1. Kerapatan pohon masak tebang pada daur kedua berdasarkan hasil simulasi siklus tebang 25, 30 dan 35 tahun (Ripe trees density at the second cycle based on cutting cycle simulation of 25,30 , and 35 years)

\begin{tabular}{|c|c|c|c|c|c|}
\hline Siklus tebang & Kelas diameter & Meranti & $\begin{array}{c}\text { Dipt non } \\
\text { meranti }\end{array}$ & Komersial lain & Jumlah \\
\hline \multirow{3}{*}{25 tahun } & $40-49 \mathrm{~cm}$ & 2,01 & 1,63 & 2,15 & 5,79 \\
\cline { 2 - 6 } & $50-59 \mathrm{~cm}$ & 0,9 & 0,5 & 0 & 1,4 \\
\cline { 2 - 6 } & $60 \mathrm{~cm}$ up & 2,14 & 0,3 & 8,01 & 10,45 \\
\hline \multirow{3}{*}{30 tahun } & $40-49 \mathrm{~cm}$ & 2,29 & 2,12 & 2,26 & 6,67 \\
\cline { 2 - 6 } & $50-59 \mathrm{~cm}$ & 1,11 & 0,57 & 0 & 1,68 \\
\cline { 2 - 6 } & $60 \mathrm{~cm}$ up & 2,83 & 0,31 & 10,66 & 13,8 \\
\hline \multirow{3}{*}{35 tahun } & $40-49 \mathrm{~cm}$ & 2,48 & 2,57 & 2,31 & 7,36 \\
\cline { 2 - 6 } & $50-59 \mathrm{~cm}$ & 0,03 & 0,01 & 0 & 0,04 \\
\cline { 2 - 6 } & $60 \mathrm{crn}$ up & 3,48 & 0,31 & 13,3 & 17,09 \\
\hline
\end{tabular}


Berdasarkan hasil inventarisasi tegakan sebelum penebangan (ITSP) pada hutan primer di lokasi penelitian diketahui bahwa kerapatan tegakan berdiameter $50 \mathrm{~cm}$ ke atas (masak tebang) sebesar 13,41 pohon/ha (PT.GM, 2000). Sementara itu, berdasarkan hasil simulasi model pertumbuhan tegakan dalam penelitian ini, dapat diproyeksilan kerapatan tegakan masak tebang pada siklus tebang 25, 30 dan 35 tahun masingmasing sebesar 11,85 pohon/ha; 15,48 pohon/ha dan 17,3 pohon/ha. Dengan demikian siklus tebang sistem TPTI selama 30 tahun adalah yang paling sesuai, karena kerapatan tegakan telah pulih seperti semula sebagai dasar penetapan pengelolaan hutan produksi lestari.

\section{E. Evaluasi Model}

Evaluasi model dilakukan dengan cara membandingkan hasil proyeksi dan komposisi tegakan pada model (expected) dengan data dinamika struktur dan komposisi tegakan tinggal hasil pengukuran langsung di lapangan (observed). Data dinamika struktur dan komposisi tegakan tinggal merupakan data hasil pengukuran seri PUP pada blok sistem TPTI.

Tabel(Table) 2. Perbandingan data hasil pengukuran (PUP) dengan hasil pemodelan (Comparing between field data and modelling data)

\begin{tabular}{|c|c|c|c|c|c|c|c|c|}
\hline No & $\begin{array}{c}\text { Kelompok } \\
\text { pohon }\end{array}$ & $\begin{array}{c}\text { Kelas } \\
\text { diameter }\end{array}$ & $\begin{array}{c}\text { Data PUP } \\
(\mathrm{O})\end{array}$ & $\begin{array}{c}\text { Hasil model } \\
\text { (E) }\end{array}$ & $(\mathrm{O}-\mathrm{E})$ & $(\mathrm{O}-\mathrm{E})^{2}$ & $(\mathrm{O}-\mathrm{E})^{2} / \mathrm{E}$ & $\begin{array}{c}\text { Jumlah } \\
\text { data }\end{array}$ \\
\hline 1 & \multirow{6}{*}{ Meranti } & $10-19$ & 2,550 & 4,284 & $-1,734$ & 3,007 & 0,702 & 1 \\
\hline 2 & & $20-29$ & 1,871 & 0,707 & 1,164 & 1,354 & 1,915 & 2 \\
\hline 3 & & $30-39$ & 2,345 & 1,257 & 1,088 & 1,184 & 0,942 & 3 \\
\hline 4 & & $40-49$ & 1,581 & 1,145 & 0,437 & 0,191 & 0,167 & 4 \\
\hline 5 & & $50-59$ & 1,225 & 0,975 & 0,250 & 0,063 & 0,064 & 5 \\
\hline 6 & & 60 up & 1,581 & 1,179 & 0,402 & 0,162 & 0,137 & 6 \\
\hline 7 & \multirow{6}{*}{$\begin{array}{l}\text { Dipt non } \\
\text { meranti }\end{array}$} & $10-19$ & 0,707 & 1,664 & $-0,957$ & 0,916 & 0,551 & 7 \\
\hline 8 & & $20-29$ & 0,707 & 0,922 & $-0,215$ & 0,046 & 0,050 & 8 \\
\hline 9 & & $30-39$ & 1,581 & 1,109 & 0,472 & 0,223 & 0,201 & 9 \\
\hline 10 & & $40-49$ & 1,225 & 1,118 & 0,107 & 0,011 & 0,010 & 10 \\
\hline 11 & & $50-59$ & 1,225 & 0,894 & 0,330 & 0,109 & 0,122 & 11 \\
\hline 12 & & 60 up & 0,707 & 0,860 & $-0,153$ & 0,023 & 0,027 & 12 \\
\hline 13 & \multirow{6}{*}{$\begin{array}{l}\text { Komersial } \\
\text { lain ditebang }\end{array}$} & $10-19$ & 1,225 & 0,707 & 0,518 & 0,268 & 0,379 & 13 \\
\hline 14 & & $20-29$ & 1,225 & 0,707 & 0,518 & 0,268 & 0,379 & 14 \\
\hline 15 & & $30-39$ & 1,581 & 1,304 & 0,277 & 0,077 & 0,059 & 15 \\
\hline 16 & & $40-49$ & 1,225 & 1,225 & 0,000 & 0,000 & 0,000 & 16 \\
\hline 17 & & $50-59$ & 1,225 & 0,707 & 0,518 & 0,268 & 0,379 & 17 \\
\hline 18 & & 60 up & 0,707 & 1,661 & $-0,954$ & 0,911 & 0,548 & 18 \\
\hline 19 & \multirow{6}{*}{$\begin{array}{l}\text { Komersial } \\
\text { lain tidak } \\
\text { ditebang }\end{array}$} & $10-19$ & 1,225 & 0,707 & 0,518 & 0,268 & 0,379 & 19 \\
\hline 20 & & $20-29$ & 1,581 & 1,425 & 0,156 & 0,024 & 0,017 & 20 \\
\hline 21 & & $30-39$ & 1,581 & 1,510 & 0,071 & 0,005 & 0,003 & 21 \\
\hline 22 & & $40-49$ & 2,345 & 0,943 & 1,402 & 1,965 & 2,083 & 22 \\
\hline 23 & & $50-59$ & 2,121 & 0,707 & 1,414 & 2,000 & 2,828 & 23 \\
\hline 24 & & 60 up & 1,225 & 1,273 & $-0,048$ & 0,002 & 0,002 & 24 \\
\hline
\end{tabular}

Keterangan $=$ O: Observed (diamati), E: Expected (diharapkan)

Dengan $\alpha=0,05$ dan $\mathrm{dk}=23$ maka tabel $\aleph_{0,95}^{2}=35,2$

Kesimpulan: Terima $\mathrm{Ho}=$ data pengamatan dan harapan tidak berarti $=$ homogen 


\section{KESIMPULAN DAN SARAN}

\section{A. Kesimpulan}

Model pertumbuhan dan hasil tegakan tinggal pada hutan alam campuran dapat dibuat menggunakan diagram alir dengan memanfaatkan fungsi ingrowth, upgrowth, mortality, efek tebangan serta dinamika kerapatan tegakan (N/ha dan $\mathrm{B} / \mathrm{ha}$ ) pada masing-masing tegakan tinggal.

Kerapatan pohon masak tebang juga dipengaruhi oleh lamanya waktu siklus tebang. Simulasi model pertumbuhan tegakan tinggal sistem TPTI menggunakan siklus tebang 25, 30 dan 35 tahun menghasilkan kerapatan pohon masak tebang masing-masing sebanyak 11,85 $\mathrm{phn} / \mathrm{ha}, 15,48 \mathrm{phn} / \mathrm{ha}$ dan $17,13 \mathrm{phn} / \mathrm{ha}$.

\section{B. Saran}

Untuk menciptakan pengelolaan hutan alam produksi yang lestari, maka penetapan target produksi perusahaan harus disesuaikan dengan dinamika pertumbuhan dan hasil tegakan tinggal. Pemodelan dapat memberi gambaran target produksi yang realistis berdasarkan pertumbuhan, struktur dan komposisi tegakan tinggal serta siklus tebang yang ditetapkan.

\section{DAFTAR PUSTAKA}

Buongiorno J., B.R. Michie BR. 1980. A Matrix Model of Uneven-Aged Forest Management. Journal of Forest Science 26(4):609625 .

Buongiorno J., L. Peyron, F. Houber, dan M. Bruciamaccrue. 1995. Growth and Management Mixed Species Uneven-Aged Forest in the French Jura. Journal of Forest Science 41(3):24-39.

Coates K.D., J.B. Philip. 1997. A Gap-Based Approach for Development of Silvicultural System to Address Ecosystem Management Objectives. Journal Forest Ecology and Management 99 (1997): 337-35.

Departemen Kehutanan Republik Indonesia. 2009. Peraturan Menteri Kehutanan No.P.11/Menhut-II/2009 tentang Sistem Silvikultur dalam Areal ijin Usaha Pemanfaatan Hasil Hutan Kayu di Hutan Produksi. Departemen Kehutanan RI, Jakarta.
Elias, S. Manan dan U. Rosalina. 1997. Studi Hasil Penerapan Pedoman Tebang Pilih Indonesia dan Tebang Pilih Tanam Indonesia di Areal HPH PT Kiani Lestari dan PT Narkata Rimba, Kalimantan Timur. Fakultas Kehutanan. Institut Pertanian Bogor. Bogor.

Favrichon V. 1998. Modeling the Dynamics and Species Composition of Tropical Mixed Species Uneven-Aged Natural Forest. Journal of Forest Science 44 (1): 58-69

Favrichon V., dan Y.C. Kim. 1998. Modelling the Dynamics of a Lowland Mixed Dipterocarp Forest Stand: Application of a Density-Dependent Matric Model. In Bertault JG, Kadir, editors. Silvicultural Research in A Lowland Mixed Dipterocap Forest of East Kalimantan. The Contributions od STREK Project, CIRAD-Foret, FORDA and PT Inhutani I. CIRAD Forest Publication: 229-245.

PT. Gunung Meranti. 2000. Rencana Karya Pengusahaan Hutan II PT Gunung Meranti periode 1997-2016. Banjarmasin.

Fyllas N.M., P.I. Politi, A. Galanidis, P.G. Dimitrakopoulo, dan M. Arianoutsou. 2010. Simulating Regeneration and Vegetation Dynamics in Mediterranean Coniferous Forest. Journal of Ecology Modelling 34(2): 234-248.

Indrawan A. 2003. Verifikasi Model Sistem Pengelolaan Tegakan Hutan Alam setelah Penebangan dengan Sistem Tebang Pilih Tanam Indonesia. Jurnal Manajemen Hutan Tropika. Vol.IX No. 2 JuliDesember 2003: 33-42.

Sist P., J.G. Bertault. 1998. Reduced Impact Logging Experiment: Impact at Harvesting Intensities and Logging Techniques at Stand Gamage. Silvicultural research in a low land mixed dipterocarp forest of east Kalimantan. The contribution of STREK Project CIRAD-Forest-FORDA-PT Inhutani I Jakarta.

Stuckle I.C., C.A. Siregar, Supriyanto, J. Kartana. 2001. Forest Health Monitoring to Monitor the Sustainability of Indonesian Tropical Rain Forest. ITTO and Seameo Biotrop. 
Suhendang E. 1998. Pengukuran Riap Diameter Pohon Meranti (Shorea sp.) pada Hutan Alam Bekas Tebangan. Makalah Diskusi: Pertumbuhan dan Hasil Tegakan. Pusat Penelitian dan Pengembangan Hutan dan Konservasi Alam. Bogor.

Vanclay, J.K. 2001. Modelling Forest Growth and Yield. Applications to Mixed Tropical Forest. Royal Veterinary and Agriculture University, Copenhagen-Denmark. CABI Publishing.
Volin V.C, dan J. Buongiorno. 1996. Effect of Alternative Management Regimes on Forest Stand Structure, Species Composition and Income: A Model for the Italian Dolomites. Journal of Forest Ecology and Management 87:107-125.

Wahyudi, A. Indrawan, I. Mansur, P. Pamoengkas, 2010. Evaluasi Struktur dan Komposisi Tegakan Tinggal pada Sistem Tebang Pilih Tanam Jalur. Jurnal Nusa Sylva Vol.10 No.2/2010: 98-109. 